\title{
UJI COBA PENAMBAHAN TEPUNG TULANG IKAN TUNA PADA KOMPOS TERHADAP TANAMAN JAGUNG TAHUN 2017 \\ (Studi Kandungan Unsur Hara Kalsium yang Diserap Tanaman Jagung)
} Faradillah Gita Amiroh, Rachmaniyah, S. B. Eko W

\begin{abstract}
ABSTRAK
Pengolahan sampah organik yang didominasi oleh sisa kegiatan rumah tangga dan pasar tradisional seperti sisa buah-buahan, dimana sampah organik sering terbuang percuma tanpa dimanfaatkan kembali dan mudah membusuk dalam 3 hari. Pengomposan merupakan salah satu alternatif dalam pengolahan sampah. Tulang ikan tuna merupakan sampah yang dapat dimanfaatkan pada pengomposan karena mengandung tinggi Kalsium yaitu sebesar $39-40 \%$. Tujuan penelitian ini adalah untuk menganalisis kualitas Kalsium pada kompos yang dipengaruhi penambahan tepung tulang ikan tuna terhadap tanaman jagung. Dimana tanaman jagung membutuhkan 43 $\mathrm{kg}$ Kalsium per $\mathrm{Ha}$ atau 4,3\% Ca untuk pertumbuhan batang dan daun tanamannya.

Penelitian ini merupakan penelitian Pra-Eksperimental dengan desain penelitian Rancangan Eksperimental After Only Design. Terdapat 4 perlakuan dalam pembuatan kompos yang diberikan penambahan tulang ikan tuna masing-masing sebesar 1,5\%, 3\%, $4,5 \%$, dan kontrol. Replikasi sebanyak 3 kali. Kondisi yang dikendalikan selama proses pengomposan yaitu suhu, $\mathrm{pH}$, dan kelembaban. Sedangkan kondisi fisik yang diamati pada kompos yaitu kondisi tekstur, warna, dan bau/aroma. Hasil akhir yang diamati adalah $\mathrm{C} / \mathrm{N}$ rasio, Kalsium ( $\mathrm{Ca}$ ), dan penyusutan yang terjadi selama pengomposan.

Hasil pemeriksaan $\mathrm{C} / \mathrm{N}$ rasio kompos yang memenuhi syarat SNI-19-7030-2004 pengomposan yaitu perlakuan I $(13,72)$ dan perlakuan II $(17,09)$. Kandungan Kalsium (Ca) yang memenuhi standar penyerapan unsur hara Kalsium pada tanaman jagung yaitu kontrol sebesar $1,88 \%$ dan perlakuan I sebesar 4,3\%. Secara keseluruhan kompos yang paling baik dan dapat digunakan yaitu perlakuan I. Kondisi suhu, pH, kelembaban pada kompos memenuhi syarat. Berdasarkan hasil pemerikssan Ca dengan uji One Way Anova terdapat perbedaan peningkatan kandungan Kalsium (Ca) pada kompos terhadap standar penyerapan unsur hara kalsium tanaman jagung.
\end{abstract}

Kata kunci : Tepung Tulang Ikan Tuna, Kalsium, C/N rasio, Kompos.

\section{PENDAHULUAN}

Perkembangan dan pertumbuhan penduduk yang cukup pesat merupakan salah satu faktor meningkatnya timbulan sampah. Permasalahan sampah yang belum terselesaikan seperti di kota-kota besar seperti sampah organik dapat digunakan langsung dalam proses pengomposan yaitu sampah sisa sayuran, sisa buah-buahan, ampas tebu, jerami padi, dan lain-lain. Pupuk organik atau kompos dapat dibuat dengan komposisi bahan organik yang mudah didapatkan.

Menurut Sutoro dalam Marvelia (2006), kandungan hara pada tanah semakin lama semakin berkurang karena sering digunakan oleh tanaman yang hidup diatas tanah tersebut. Pada pertumbuhan tanaman, unsur hara merupakan faktor penting dimana salah satu unsur hara yang terdapat dalam suatu kompos adalah unsur hara Kalsium (Ca).

Bahan-bahan Kalsium sering dijumpai dipasaran untuk nutrisi tumbuhan yaitu dalam bentuk kapur kalsit atau dolomit. Penggunaan kapur dalam jangka panjang memiliki pengaruh yang kurang menguntungkan bagi keseimbangan hara dalam tanah. Kapur juga menyebabkan kadar bahan organik tanah merosot dengan cepat karena aktivitas mikroorganisme perombak menjadi lebih aktif. Namun terdapat bahan-bahan lain yang mengandung tinggi Kalsium disekitar masyarakat yang tidak dimanfaatkan lagi dan terbuang percuma seperti tulang ikan tuna.

Tepung tulang ikan tuna mengandung tinggi Kalsium sebesar $39-40 \%$. Tulang ikan tuna dapat ditambahkan dalam 
proses pengomposan karena sangat ekonomis dan mudah didapatkan.

Jagung (Zea mays sp.) merupakan jenis pangan yang mengalami peningkatan dalam setiap produksinya. pertumbuhan pada tanaman jagung dapat dipengaruhi beberapa faktor seperti pemupukan, kondisi tanah, iklim, dan tanaman. Tanaman jagung relatif membutuhkan hara untuk dapat tumbuh optimal, sehingga pemberian pupuk merupakan salah satu faktor kunci bagi keberhasilan budidaya jagung.

Berdasarkan latar belakang tersebut, maka peneliti ingin melakukan penelitian Penambahan Tepung Tulang Ikan Tuna Kompos Terhadap Kandungan Unsur Hara Kalsium Yang Diserap Tanaman Jagung. Tujuan dari penelitian ini adalah menganalisis kualitas Kalsium pada kompos yang dipengaruhi penambahan tepung tulang ikan tuna terhadap standar penyerapan unsur hara Kalsium tanaman jagung.

\section{METODE PENELITIAN}

Jenis penelitian yang digunakan yaitu pra-eksperimental, dimana eksperimen ini banyak variabel luar dan sumber invalisitas yang tidak terkendali, banyak validitas internal maupun eksternal tidak dapat dipenuhi. (Budijanto, Didik dan Prajoga, 2005)
Menggunakan rancangan Eksperimental After Only Design. Dengan replikasi sebanyak 3 kali. Sampel yang digunakan yaitu sampah sisa buah-buahan didapat dari Pedagang Kaki Lima Rujak Buah Daerah Dr. Soetomo dan Tulang Ikan Tuna didapat dari Pasar Pabean. Dosis tepung tulang ikan tuna yang diaplikasikan terdapat 3 perlakuan yaitu sebesar 1,5\%; 3\%; 4,5\%. Waktu penelitian dilaksanakan pada bulan Januari-Juni 2017. Variabel bebas pada penelitian ini dosis Tepung Tulang Ikan Tuna. Variabel terikat pada penelitian ini adalah kadar kalsium kompos terhadap standar penyerapan unsur hara tanaman jagung. Variabel terkendali pada penelitian ini adalah suhu, $\mathrm{pH}$, kelembaban.

Pada penelitian ini menggunakan analisis data jenis one way Anova karena karakteristik jumlah kelompok yang diteliti lebih dari dua dengan menggunakan SPSS.

HASIL PENELITIAN
PEMBAHASAN
Hasil Pemeriksaan C/N Rasio
Hasil rata-rata pemeriksaan
laboratorium pada kompos jadi dengan
$\begin{array}{lll}\text { parameter } \mathrm{N} \text { Rasio dan } & \text { Kalsium } \\ \text { adalah } & \text { sebagai } & \text { berikut: }\end{array}$

Tabel 1

HASIL RATA-RATA PEMERIKSAAN LABORATORIUM PARAMETER C/N RASIO DAN UNSUR HARA KALSIUM

\begin{tabular}{ccc}
\hline Perlakuan & C/N Rasio & Kalsium \\
\hline Kontrol & 8,01 & $1,88 \%$ \\
\hline I & 13,72 & $4,3 \%$ \\
\hline II & 17,09 & $9,06 \%$ \\
\hline III & 22,11 & $13,15 \%$ \\
\hline
\end{tabular}

Menurut SNI-19-7030-2004 standar C/N rasio pada kompos yaitu sebesar 10-20. Berdasarkan standar tersebut terdapat 2 kelompok yang tidak memenuhi syarat $\mathrm{C} / \mathrm{N}$ Rasio pada kompos yaitu kelompok Kontrol dan kelompok Perlakuan III. Sedangkan 2 kelompok yang memenuhi syarat C/N Rasio yaitu Perlakuan I dan Perlakuan II.

Pada penelitian ini, kelompok Kontrol menunjukkan bahwa rendahnya $\mathrm{C} / \mathrm{N}$ Rasio pada kompos karena bahan yang digunakan hanya sampah sisa buahbuahan yang memiliki kandungan Nitrogen yang tinggi untuk sintesis protein serta banyaknya gas amonia yang dihasilkan sehingga kurangnya bahan yang kaya akan Karbon seperti jerami, sekam, dan serbuk-serbuk kayu. Hasil C/N Rasio yang rendah dapat mengakibatkan nitrogen akan dibebaskan dan berakumulasi dalam bentuk amoniak $\left(\mathrm{NH}_{4}\right)$ sehingga $\mathrm{pH}$ 
yang tinggi mengakibatkan berkurangnya bakteri metagonik.

Pada perlakuan III kondisi C/N Rasio yang dihasilkan cukup tinggi yaitu sebesar 22,11. Berdasarkan hasil tersebut, tingginya $\mathrm{C} / \mathrm{N}$ Rasio pada kompos disebabkan oleh belum terdekomposisinya kompos secara sempurna atau $\mathrm{C} / \mathrm{N}$ rasio belum mengalami penurunan secara maksimal sehingga $\mathrm{C} / \mathrm{N}$ rasio $>20$. Bila $\mathrm{C} / \mathrm{N}$ Rasio terlalu tinggi, nitrogen akan dikonsumsi dengan cepat oleh bakteri metanogenik untuk pertumbuhannya dan hanya sedikit yang bereaksi dengan Karbon sehingga akibatnya gas yang dihasilkan rendah.

Menurut Suhut Simamora dan Salundik (2006) dalam bukunya Meningkatkan Kualitas Kompos, jumlah penyerapan unsur hara Kalsium pada tanaman jagung sebesar 4,3 kg Ca atau 4,3\% sehingga terdapat 2 kelompok perlakuan yang tidak memenuhi syarat yaitu kelompok Perlakuan II dan Perlakuan III.

Menurut R Kusmiadi dkk (2014), kompos yang mengandung Kalsium dalam jumlah cukup mampu memacu aktivitas mikroorganisme dalam menguraikan bahan organik. Namun, bila kadar kapur dalam kompos terlalu tinggi, dapat berakibat menguapnya unsur Nitrogen. Menurut Sanchez (1992) dalam penelitian Abdul Rasyid dkk (2014), aplikasi kapur $\mathrm{CaCO}_{3}$ yang berlebihan dapat mengikar hara $\mathrm{P}$ sehingga tidak tersedia bagi tanaman. Hal ini disebabkan Kapur melepaskan Ca yang selanjutnya dapat membentuk ikatan dengan $P$ sehingga ketersediaan $P$ semakin rendah.

\section{Hasil Pemeriksaan Suhu, pH, dan Kelembaban}

Dalam suatu pengomposan dipengaruhi oleh $\mathrm{pH}$, suhu, dan kelembaban Rerata hasil pengamatan pada kompos yaitu

Tabel 2

HASIL PENGAMATAN PADA KOMPOS JADI

\begin{tabular}{cccc}
\hline Perlakuan & pH & Suhu & Kelembaban \\
\hline Kontrol & 7,33 & $28{ }^{\circ} \mathrm{C}$ & $52,87 \%$ \\
\hline I & 7,25 & $26,5^{\circ} \mathrm{C}$ & $51,85 \%$ \\
\hline II & 7,20 & $26^{\circ} \mathrm{C}$ & $52,38 \%$ \\
\hline III & 7,36 & $27,5^{\circ} \mathrm{C}$ & $55,68 \%$ \\
\hline
\end{tabular}

Kondisi pH, suhu, dan kelembaban merupakan faktor lingkungan yang dapat mempengaruhi proses pengomposan berlangsung. Jumlah rerata $\mathrm{pH}$ pada tabel diatas didapat keempat kelompok perlakuan telah memenuhi persyaratan SNI-19-70302004. Dimana $\mathrm{pH}$ yang terdapat pada kompos yaitu mendekati netral atau sebesar 6,8-7,49. Sedangkan kondisi suhu pengomposan pada penelitian ini memiliki suhu yang rendah, hal ini dikarenakan keadaan bahan kompos yang digunakan memiliki kadar air yang cukup tinggi yang menyebabkan bakteri kekurangan oksigen dan hilangnya poripori partikel kompos.

Suhu/temperatur kompos akan mengalami kenaikan mencapai $30-60^{\circ} \mathrm{C}$ sehingga campuran bahan baku pada kompos cukup mengandung unsur nitrogen dan karbon yang dapat mampu menunjang aktivitas mikroorganisme.

Jumlah rerata kelembaban pada tabel didapat keempat kelompok perlakuan telah memenuhi syarat pengomposan SNI-19-7030-2004. Kelembaban pada proses pengomposan memegang peranan penting dalam metabolisme mikroba yang secara tidak langsung berperan dalam menyuplai oksigen. Pada penelitian ini bahan yang digunakan memiliki kelembaban yang sangat tinggi, sehingga terdapat penambahan perlakuan yaitu dengan cara menambahkan sampah kering (daun-daunan) untuk mempertahankan kandungan air agar tetap ideal dalam proses pengomposan. 
Pemeriksaan Kondisi Fisik (Tekstur, Warna, dan Bau) pada Kompos

Pada penelitian ini kondisi fisik tekstur keempat perlakuan memiliki tekstur yang remah (mudah hancur) yang merupakan salah satu ciri-ciri dari kompos matang. Kondisi fisik warna pada kompos jadi dari keempat perlakuan memiliki kondisi yang sama yaitu hitam dan cokelat tua.
Pengamatan kondisi fisik selain tekstur dan warna adalah bau. Pada kondisi fisik bau pada keempat kelompok perlakuan memiliki kondisi yang sama yaitu berbau tanah. Menurut Mundiatun (2013), apabila terjadi kondisi aroma/bau yang busuk atau tidak sedap pada kompos maka terjadi fermentasi anaerobik yang dapat menghasilkan senyawa yang membahayakan bagi tanaman.

\section{Jumlah Penyusutan Kompos Jadi}

Tabel 3

JUMLAH PENYUSUTAN BAHAN KOMPOS

\begin{tabular}{cc}
\hline Perlakuan & Rata-rata Penyusutan \\
\hline Kontrol & $61 \%$ \\
\hline I & $61,7 \%$ \\
\hline II & $61,08 \%$ \\
\hline III & $62,06 \%$ \\
\hline
\end{tabular}

Penyusutan bobot kompos yang terjadi dalam proses pengomposan sejalan dengan kematangan kompos. Menurut Wahyono dkk (2013) interval penyusutan yang baik bagi proses pengomposan yaitu $61-95 \%$. Pada tabel diatas, penyusutan pada bahan kompos telah memenuhi syarat proses pengomposan.

Berat bahan kompos pada akhir proses pengomposan mengalami penyusutan yang sangat berarti. Penyusutan disebabkan saat proses pengomposan terjadi perombakan pada bahan-bahan kompos oleh sejumlah mikroorganisme yang mana mikroorganisme tersebut merubah bahan kompos (bahan organik) menjadi produk metabolism berupa $\mathrm{CO} 2, \mathrm{H} 2 \mathrm{O}$, humus dan energy. Bahan kompos matang akhir akan mengalami penurunan volume/berat lebih dari $60 \%$ dari berat awal. (Wahyono, et al. 2013)

\section{KESIMPULAN DAN SARAN}

\section{Kesimpulan}

1. Kandungan $\mathrm{C} / \mathrm{N}$ rasio yang memenuhi syarat pengomposan adalah kelompok perlakuan I (dosis tepung tulang ikan tuna 1,5\%) sebesar 13,60 dan perlakuan II (dosis tepung tulang ikan tuna 3\%) sebesar 17,09.

2. Kandungan unsur hara Kalsium (Ca) yang memenuhi syarat SNI-19-
7030-2004 adalah semua kelompok perlakuan, sedangkan menurut standar penyerapan unsur hara Kalsium terhadap tanaman jagung yang memenuhi syarat adalah kelompok kontrol (dosis penambahan tepung tulang ikan tuna) sebesar $1,88 \%$ dan perlakuan I (dosis tepung tulang ikan tuna $1,5 \%$ ) sebesar $4,3 \%$.

3. Kondisi $\mathrm{pH}$, suhu, dan kelembaban selama proses pengomposan pada seluruh kelompok perlakuan telah memenuhi syarat. Dimana $\mathrm{pH}$ terendah pada perlakuan II (dosis tepung tulang ikan tuna 3\%) sebesar 7,20 dan $\mathrm{pH}$ tertinggi pada perlakuan III (dosis tepung tulang ikan tuna 4,5\%) sebesar 7,36 serta suhu yang rendah dan mendekati suhu kamar adalah pada perlakuan I (dosis tepung tulang ikan tuna $1,5 \%$ ) sebesar $26,5^{\circ} \mathrm{C}$, perlakuan II (dosis tepung tulang ikan tuna 3\%) sebesar $26^{\circ} \mathrm{C}$, dan perlakuan III (dosis tepung tulang ikan tuna $4,5 \%$ ) sebesar $27,5^{\circ} \mathrm{C}$. Sedangkan kelembaban yang terendah pada perlakuan I (dosis tepung tulang ikan tuna $1,5 \%$ ) sebesar $51,85 \%$ dan tertinggi pada perlakuan III (dosis tepung tulang ikan tuna $4,5 \%$ ) sebesar $55,68 \%$. 
4. Kondisi fisik dari segi tekstur, warna, dan bau pada seluruh kelompok perlakuan telah memenuhi syarat kompos jadi. Pada perlakuan I (dosis tepung tulang ikan tuna $1,5 \%)$ adalah tekstur dan warna yang paling baik yaitu remah dan halus dengan warna kehitaman. Sedangkan bau/aroma pada seluruh perlakuan adalah aroma tanah pada umumnya.

5. Banyaknya penyusutan pada proses pengomposan, seluruh kelompok perlakuan telah memenuhi standar penyusutan kompos menurut Wahyono dkk (2003). Penyusutan terendah pada kelompok Kontrol (tanpa tepung tulang ikan tuna) sebesar $61 \%$ dan penyusutan tertinggi pada perlakuan III (dosis tepung tulang ikan tuna 4,5\%) sebesar $62,06 \%$.

6. Produk kompos yang memenuhi standard secara keseluruhan dan dapat diaplikasikan pada tanaman jagung yaitu Perlakuan I dimana dosis tepung tulang ikan tuna sebesar $1,5 \%$.

\section{Saran}

a. Bagi Masyarakat

Diharapkan bagi masyarakat pedagang-pedagang ikan tidak membuang percuma tulang ikan yang telah dipisah dengan dagingnya. Pemanfaatan dapat dilakukan dengan cara diaplikasikan pada pengomposan.

b. Bagi Peneliti Lain
1. Perlu dilakukan penelitian selanjutnya yaitu mengaplikasikan kompos secara langsung pada tanaman jagung
2. Pembuatan kompos yang dikhususkan pada standar penyerapan unsur hara Kalsium (Ca) pada tanaman lain seperti tanaman padi.

3. Menambah parameter untuk meningkatkan kualitas unsur hara kompos seperti unsur hara Phospor dan Kalium.

4. Mengukur kadar air saat proses pengomposan.

\section{DAFTAR PUSTAKA}

Alex, 2015. Sukses Mengolah Sampah Organik Menjadi Pupuk Organik. Yogyakarta: Penerbit Pustaka Baru Press.

Awalita, Marvelia., 2006, Produksi Tanaman Jagung (Zea Mays L. Saccharata) yang Diperlakukan dengan Kompos Kascing dengan Dosis yang Berbeda. Buletin Anatomi dan Fisiologi: Universitas Diponegoro.

B Damanik, Abdul Rasyid, dkk. 2014. Dinamika $\mathrm{N}-\mathrm{NH}_{4}$ dan $\mathrm{N}-\mathrm{NO}_{3}$ Akibat Pemberian Pupuk Urea Dan Kapur $\mathrm{CaCO}_{3}$ Pada Tanah Inceptisol Kwala Bekala Dan Kaitannya Terhadap Pertumbuhan Tanaman Jagung. Jurnal Agroekoteknologi. Fakultas Pertanian: Universitas Sumatera Utara Medan.

Badan Penyuluhan dan Pengembangan SDM Pertanian, 2015. Pelatihan Teknis Budidaya Jagung Bagi Penyuluh Pertanian dan Babinsa Pembuatan Pupuk Organik. https://www.google.co.id/url?sa=t\&s ource=web\&rct=j\&url=http://www.p ertanian.go.id/pajale2015/h1.1.JARA K\%2520TANAM.pdf. Diakses pada tanggal 26 November 2016.

Budijanto, Didik dan Prajoga. 2005. Metodologi Penelitian. Surabaya: Percetakan Duatujuh.

Dewi Moelyaningrum, Anita, dkk. 2013. Penggunaan Dolomit (MgCa(CO3)2) Sebagai Penstabil pH Pada Komposting Sampah Dapur Berbasis Dekomposisi Anaerob dan Aerob. Jurnal IKESMA: Universitas Jember.

Gunawan, dkk, 2015. Studi Pemanfaatan Sampah Organik Sayuran Sawi (Brassica juncea L.) dan Limbah Rajungan (Portunus pelagicus) untuk Pembuatan Kompos Organik Cair. Vol.8, No.1, Hal 37. Jurnal Pertanian dan Lingkungan. Universitas Bangka Belitung.

http://download.portalgaruda.org/art icle.php?article $=435400 \& v a l=5433 \&$. Diakses pada tanggal 29 Januari 2017.

Harianto, Bagus, 2007. Cara Praktis Membuat Kompos. Jakarta: PT. AgroMedia Pustaka. 
Hety Indriani, Yovita, 2013. Membuat Kompos Kilat. Jakarta: Penerbit Swadaya.

Kementerian Kelautan dan Perikanan RI. Badan Pengembangan SDM dan Pemberdayaan Masyarakat KP. http://bpppbelawan.bpsdmkp.kkp.go. id/. Diakses pada tanggal 2 Maret 2017.

Lingga, Pinu., Marsono, 2013. Petunjuk Menggunakan Pupuk. Jakarta: Penebar Swadaya.

Marta'ati, Marisa, 2015. Pengaruh Penambahan Tepung Tulang Ikan Tuna (Thunnus sp.) Dan Proporsi Jenis Shortening Terhadap Sifat Organoleptik Rich Biskuit. Pendidikan Tata Boga: Universitas Surabaya.

Mundiatun, 2013. Faktor Penentu Kualitas Kompos. Widyaiswara Departemen PLH PPPPTK BOE. Kota Malang. Diakses pada tanggal 1 Februari 2017. http://www.vedcmalang.com/pppptk boemlg/index.php/menuutama/plh/5 65-peduli-kesehatan-ii.

Musafir Wellang, Rahma, 2015. Studi Kelayakan Kompos Menggunakan Variasi Bioaktivator (EM4 dan ragi), Jurnal Teknik Lingkungan. Universitas Hasanuddin Makassar : Hal. 10. http://repository.unhas.ac.id/handle/ 123456789/14398. Diakses pada tanggal 30 Januari 2017.

Nasir, Muhammad. 2013. Karakteristik Pengomposan Limbah Padat Pasar
Internasional Dengan Sistem Natural Static Pile. Tesis Pascasarkana: Institut Pertanian Bogor.

Novizan, 2002. Petunjuk Pemupukan yang Efektif. Jakarta: PT.Agromedia Pustaka.

Nuryati, Leli., dkk,2015. Outlook Komoditas Pertanian Tanaman Pangan Jagung. Pusat Data dan Sistem Informasi Pertanian Kementrian Pertanian: Jakarta.

Simamora, Suhut dan Salundik, 2006. Meningkatkan Kualitas Kompos. Jakarta: PT. AgroMedia Pustaka.

Susetya, Darma, 2015. Panduan Lengkap Membuat Pupuk Organik Untuk Tanaman. Yogyakarta: Penerbit Pustaka Baru Press.

Standar Nasional Indonesia No.19-70302004 Tentang Spesifikasi Kompos dari Sampah Organik Domestik.

Suwahyono, Untung, 2002. Petunjuk Praktis Penggunaan Pupuk Organik secara Efektif dan Efisien. Surabaya: Penebar Swadaya.

Suyono., Budiman, 2012. IImu Kesehatan Masyarakat Dalam Konteks Kesehatan Lingkungan. Jakarta: Penerbit Buku Kedokteran.

Wahyono, Sri, dkk, 2011. Membuat Pupuk Organik Granul dari Aneka Limbah. Jakarta: PT Agromedia Pustaka.

Wiratna Sujarweni, V, 2015. Statistik Untuk Kesehatan. Yogyakarta: Penerbit Gava Media. 